\title{
ANALISIS GAYA BELAJAR SANTRI BERPRESTASI PONDOK PESANTREN AN-NUR 2 BULULAWANG MALANG
}

\author{
Rachmicha Devia Putri Malawangi, M. Syahri \\ FKIP Universitas Muhammadiyah Malang, Indonesia \\ Email: dhee.rdpm@gmail.com
}

\begin{abstract}
ABSTRAK
Penelitian ini dilakukan karena hal sulit yang dilakukan santri yang bersekolah di pondok pesantren adalah waktu, bagaimana santri dapat membagi waktu belajar yang singkat, dengan rutinistas yang padat. Tujuan penelitian ini yaitu Untuk mengetahui (1) gaya belajar santri berprestasi di pondok pesantren. (2) bagaimana santri mengatasi waktu yang kurang efektif untuk belajar, dan mengerjakan tugas. (3) faktor pendukung santri berprestasi di pondok pesantren. Jenis penelitian adalah penelitian deskriptif dengan subjek penelitian adalah santri di pondok pesantren An-Nur Bululawang. Data diambil menggunakan hasil tes wawancara, dokumentasi, dan observasi. Hasil data yang diperoleh berupa hasil tes wawancara, obeservasi dan dokumentasi kemudian dianalisis. Secara deskriptif, hasil penelitian menunjukan: (1) bahwa perbedaan belajar santri berprestasi dengan santri kurang berprestasi terletak pada motivasi belajar mereka. Motivasi dan semangat belajar tinggi cenderung dimiliki oleh santri berprestasi dengan belajar yang baik. (2) tidak ada cara khusus, santri berprestasi lebih pandai mengola waktu luang. (3) tidak ada faktor khusus, santri berprestasi lebih memiliki dan menanamkan motivasi kedalam diri mereka sendiri.
\end{abstract}

Kata Kunci: Gaya belajar; Prestasi belajar; Santri; Pondok Pesantren.

\begin{abstract}
This research was carried out because the difficult thing done by students who study at Islamic boarding schools is time, how students can divide short learning time, with a solid routine. The purpose of this study is to find out (1) the learning styles of high-achieving students in Islamic boarding schools. (2) how students deal with less effective time for learning and doing assignments. (3) Supporting factors of high-achieving students in Islamic boarding schools. This type of research is a descriptive study with research subjects are students in An-Nur Bululawang Islamic boarding school. Data was collected using interview test results, documentation, and observation. The results of the data obtained in the form of interviews, observation and documentation were then analyzed. Descriptively, the results of the study show: (1) that the difference in the learning of students with high achievements and underachievement of students lies in their learning motivation. Motivation and enthusiasm for high learning tend to be owned by high achieving students with good learning. (2) there is no special way students achievers are better at managing leisure time. (3) there is no specific factor students with more achievement have and instil motivation into themselves.
\end{abstract}

Keywords: Learning style; Learning achievement; Student; Islamic boarding school.

\section{PENDAHULUAN}

Pendidikan merupakan tonggak bagi perkembangan hidup manusia, maka dari itu manusia sejak dini harus mendapatkan pendidikan yang layak, dalam UUD 1945 alenia keempat tertulis "mencerdaskan kehidupan bangsa", disini dapat dilihat betapa pentingnya pendidikan, dimulai dari PAUD, TK, SD, SMP, SMA dan kuliah, bahkan anak sejak dalam perut pun layak mendapatkan pendidikan.

Pendidikan kini banyak macamnya, ada pendidikan umum seperti, IPA, IPS, Bhs. Indonesia, Bhs. Inggris, Matematika, adapula pendidikan diniyah, pendidikan diniyah sendiri mencakup pendidikan yang berbau agama seperti Fiqih, AlQuran Hadist, Aqidah Akhlaq, nahwu, 
aswaja atau sering disebut SKI (Sejarah Kebudayaan Islam). Untuk mata pelajaran diniyah sendiri biasanya terdapat di sekolah yang berbasis agama, dalam artian pendidikan agama lebih diprioritaskan dari pada mata pelajaran umumnya, sekolah yang dimaksud penulis adalah MI, MTS, MA, selain di sekolah mata pelajaran diniyah juga diajarkan di pondok pesantren.

Pondok Pesantren mempunyai dua pengertian, pesantren merupakan tempat belajar, yang diambil dari bahasa India santri yang berati orang yang mengetahui kitab suci. Pesantren sendiri pada dasarnya untuk belajar para santri (siswa), sedangkan Pondok berasal dari bahasa arab funduq yang berarti rumah atau hotel. Dari penjelasan tersebut dapat disimpulkan bahwa pesantren merupakan tempat atau rumah bagi para santri, biasanya para santri yang ada di Pondok Pesantren adalah santri yang tempat tinggal atau tempas asal yang jauh, santri juga harus berpisah dari keluarganya, dan hanya dituntut untuk belajar tanpa adanya hubungan dari dunia luar, tanpa ada alat komunikasi. Seiring berkembangnya jaman peraturan demi peraturan mulai berubah, banyak pondok pesantren yang menyediakan sekolah, bahkan dengan kualitas internasional, yeng bertujuan agar para santri tidak hanya mempelajari ilmu diniyah, perbedaan sekolah di pesantren biasanya santri mendapatkan pemdidikan diniyah dua kali yakni di sekolah dan di pesantren, dan cara pengejarannya berbeda, untuk diniyah di sekolah guru mengajarkan dasar-dasarnya saja, sedangkan di pondoknya santri diajarkan lebih detail, karena tujuan dari pondok pesantren itu sendiri mengajarkan agama.

Pemahaman diartikan sebagai penyerapan, seseorang dapat dikatan paham apabila mengerti benar dan mempu menjelaskan tentang sesuatu tersebut, "pemahaman bukanlah suatu fakta yang tinggal ditemukan, melainkan suatu bentukan dari orang yang sedang mempelajarinya. Pamahaman mengandung suatu proses, pemahaman seseorang adalah bentukan orang itu sendiri. (Mulyono 2012).

Salah satu yang sulit dilakukan santri yang bersekolah di pondok pesantren adalah waktu, bagaimana santri dapat membagi waktu belajar yang singkat, dengan rutinistas yang padat seperti, pagi santri harus sekolah dan di pesantren santri harus mengikuti kegiatan lain, untuk sekolah kitab, mengaji, dan macammacam kegitan lainnya sampai waktu berakhirnya yaitu pukul 21.00, jika diteliti dan diperhatikan lagi dengan kegiatan sebnayak di atas kapan waktu santri untk belajar atau mengulang pelajar yang diajarkan guru di sekolah, sedangkan kini diterapkannya sistem fullday.

Berdasarkan paparan di atas menimbulkan penulis bermotivasi untuk meneliti dan mengetahui lebih lanjut bagaimana santri atau siswa di Pondok Pesantren An-Nur II Bululawang Malang dapat berprestasi dan kapan waktu santri untuk belajar, mengerjakan tugas, dan mengulang pelajaran yang diberikan dari sekolahnya, sedangkan waktu yang didapat kurang efektif

\section{METODE}

Penelitian ini bertujuan untuk mendeskripsikan pemahaman dari santri berprestasi berdasarkan gaya belajar yang digunakan santri di pondok pesantren, mendeskrisikan bagaimana santri mengatasi waktuyangkurangkondusifuntukbelajar, dan mengerjakan tugas, serta mendeskripsikan faktor pendukung apa saja yang membuat santri dapat berprestasi di pondok pesantren. Berdasarkan tujuan tersebut maka jenis penelitian ini adalah penelitian deskriptif. Subjek dalam penelitian ini adalah santri di pondok pesantren An-Nur Bululawang.

Instrumen utama pada penelitian ini adalah peneliti. Peneliti mendesain proses 
pengumpulan data sehingga didapatkan data yang valid dan reliabel. Dalam proses pengumpulan data, peneliti menggunakan instrumen bantu lain seperti pedoman wawancara, pedoman dokumentasi, dan observasi. Pada penelitian ini, data yang dicari dikumpulkan secara langsung oleh peneliti, sehingga instrumen utama penelitian ini adalah peneliti sendiri, yang dibantu dengan instrumen bantu, yaitu tes wawancara, observasi dan dokumentasi.

Seorang pewawancara yang baik adalah seseorang yang peka terhadap situasi wawancara, melakukan pendekatan yang baik terhadap responden melalui sikap empati, bisa segera menyesuaikan diri dengan responden dan bisa menerimanya sebagaimana adanya.

Dokumentasi dalam penelitian ini dilakukanuntukmempelajari dan mendalami berbagai dokumen yang berkaitan dengan gaya belajar santri berprestasi di pondok pesantren. Dokumentasi yang digunakan dalam penelitian ini yaitu, rapor santri berprestasi dan data gaya belajar santri berprestasi di pondok pesantren.

Observasi dalam penelitian ini merupakan cara pengumpulan data untuk mendapatkan informasi dengan cara melakukan pengamatan langsung terhadap gaya belajar santri berprestasi di pondok pesantrean. agar observasi yang dikembangkan oleh guru dengan mengacu pada indikator yang telah diterapkan. Observasi dalam penelitian ini bertujuan untuk memperoleh data gaya belajar santri berprestasi di pondok pesantren.

Teknis analisis data yang akan digunakan adalah deskriptif naratif dengan menggunakan model Miles dan Huberman dalam Sugiono (2009). Ia mengungkapkan bahwa aktifitas dalam analisis data kualitatif dilakukan secara interaktif dan berlangsung secara terus menerus sampai tuntas, sehingga datanya jenuh. Ukuran kejenuhan data ditandai dengan tidak diperolehnya lagi data atau informasi baru.
Dalam analisis data kualitatif adalah penarikan kesimpulan dan verifikasi. Kesimpulan awal yang dikemukakan masih bersifat sementara, dan akan berubah bila tidak ditemukan bukti-bukti yang kuat dan mendukung pada tahap pengumpulan data berikutnya. Tetapi apabila kesimpulan yang dikemukakan pada tahap awal di dukung oleh bukti-bukti yang valid dan konsisten saat peneliti kembali ke lapangan mengumpulkan data, maka kesimpulan yang dikemukakan merupakan kesimpulan yang kredibel.

Peneliti menggunakan triangulasi data dalam pengujian keabsahan data. Secara sederhana. Dapat ditarik kesimpulan cara pengumpulan data dari berbagai sumber kemudian digabungkan atau dibandingkan kemudian ditarik sebuah kesimpulan dari berbagai data yan telah diperoleh dalam penelitian tersebut.

\section{HASIL DAN PEMBAHASAN}

Penelitian ini merupakan penelitian kualitatif yang bertujuan mencari informasi mengenai cara belajar santri berprestasi. Penelitian ini dimulai dari pencarian tiga santri peringkat teratas dan tiga santri peringkat terbawah. Penelitian diawali dari penyeleksian dari sejumlah santri yang ada dalam satu kelas. Dari beberapa tahapan tersebut kemudian diambil tiga santri dengan peringkat teratas dan tiga santri peringkat terbawah. Penyeleksian ini dilakukan karena tidak adanya korelasi antara satu data dengan data lainya. Sehingga peneliti membutuhkan analisis lebih mendalam, guna menemukan kesimpulan secara objektif.

Dari hasil observasi peneliti, akhirnya peneliti menetapkan 3 santri berprestasi dan 3 santri kurang berprestasi dari 32 santri di kelas XII di Pondok Pesantren An Nur II Bululawang. Tujuan dari penelitian ini yaitu untuk mengetahui bagaimana cara belajar santri berprestasi, bagaimana santri memanfaatkan waktu yang tidak efektif, 
dan faktor apa saja yang mempengaruhi santri berprestasi.

Gaya Belajar Santri Berprestasi di Pondok Pesantren An-Nur II Bululawang Malang

Berdasarkan dari hasil penelitian yang telah diuraikan pada pembahasan sebelumnya, bagaimana gaya belajar santri berprestasi di pondok pesantren An-Nur II Bululawang Malang, santri tidak memiliki gaya belajar secara khusus, tiap santri memiliki cara belajar sendiridan carabelajar pada umumnya, yakni menggunakan gaya belajar visual dan auditorial, gaya belajar ini yang sangat umum diminati santri. Di lingkungan Pondok Pesantren minat santri lebih banyak membaca, karena menurut santri ini sendiri membaca bisa dilakukan dimana saja, hanya dengan meminjam buku di perpustakaan, dapat dipelajari dimana saja dan kapan saja, baik itu diselasela kegiatan asrama, istirahat bahkan dijam bermain.

Gaya belajar yang dimiliki santri berprestasi, tidak ada yang khusus, santri menggunakan gaya belajar pada umumnya, hanya terfokus pada visual, dan auditorial. Dengan masing-masing memiliki cara khas tersensendiri, untuk gaya belajar visual, mata adalah alat penting untuk menangkap dan memperoleh informasi, seperti melihat gambar, membaca tulisan sehingga dapat mudah memahami apa yang telah disajikan. Jika dihadapkan dengan suara atau gerakan akan merasa sulit belajar. gaya belajar visual memiliki ciri-ciri, berbicara cenderung lebih cepat, mementingkan penampilan, baik dalam berpakaian maupun berprestasi, lebih mudah mengingat apa yang dilihat dari pada apa yang didengar, mengingat sesuatu dengan penggambaran visual, tidak mudah terganggu dengan keributan, dapat membaca dalam keadaan ramai, membaca dengan cepat dan tekun, lebih suka membaca sendiri dari pada dibacakan orang lain, tidak mudah percaya terhadap masalah sebelum melihat sendiri. Ciri bahasa tubuh yang menunjukan seseorang gaya belajar visual biasanya duduk tegak dan mengikuti pengajar atau penyaji dengan matanya.

Gaya belajar auditorial memiliki kemampuan atau kekuatan mendengar yang tajam, biasanya mereka belajar dengan metode ceramah, radio, dialog, dan berdiskusi selain itu dapat melalui nada atau lagu. Anak tipe sangat muda menangkap pelajaran yang disajikan dalam bentuk suara (ceramah), biasanya begitu guru menerangkan dia dengan cepat menangkap dan memahami bahan pelajaran, selain itu dialog, atau kata yang diucapkan temannya mudah ditangkap, dan sebaliknya dia akan kesulitan dengan pelajaran yang disajikan dengan tulisan.

Gaya belajar auditorial memiliki Ciri menonjol, saat bekerja sering berbicara sendiri, dapat mengulangi dan menirukan nada, irama dengan mudah, merasa sulit untuk menulis namun sangat senang bercerita. Lebih suka music daripada seni yg lain, mudah terganggu dengan keramaian, sering menggerakkan bibir dan mengucapkan tulisan dibuku ketika membaca, lebih mudah belajar dengan mendengarkan dan mengingat apa yang didiskusikan dari pada yang dilihat.

Ciri bahasa tubuh yang menunjukan seorang auditorial, dia sering mengulang dengan lembut kata-kata yang diucapkan oleh pengajar atau penyaji dan sering menggunakan kepalanya saat menyajikan informsai lisan dikarenakan semua informasi yang dia dapat tersimpan dimemorinya, tipe gaya belajar ini sering memandang keatas untuk memutar kemabli kasetnya.

Hasil penelitian tersebut sesuai dengan teori yang dikemukakan oleh Bobbi De Poter dan Mike Hernacki yang dikutip oleh Sukadi (2008: 95) secara umum gaya belajar manusia dibedakan menajadi tiga kelompok, yaitu gaya belajar 
visual, yang memiliki kekuatan dalam indra penglihatan, gaya belajar auditorial, gaya belajar yang lebih dominan pada indra pendengaran, gaya belajar kinestetik, gaya belajar yang mengutamakan indra prasa, atau gerakan fisik.

\section{Santri Mengatasi Waktu Yang Kurang Efektif di Pondok Pesantren An-Nur II Bululawang Malang.}

Berdasarkan hasil penelitian dari pembahasan sebelumnya, bagaimana santri mengatasi waktu yang kurang efektif di Pondok Pesantrean An-Nur II Bululawang Malang, dari santri sendiri mengutarakan bahwa tidak ada waktu yang kurang efektif hanya saja bagaimana cara memanfaatkan waktu luang agar tidak terbuang, dipadatnya waktu dan kegiatan yang dijalani akan ada waktu sela, waktu sela itulah yang dimanfaatkan oleh santri berprestasi untuk, belajar, mengerjakan tugas, dan mengulang pelajaran, baik dengan membaca atau merangkum buku yang dipinjam dari perpustakaan, santri berprestasi di Pondok Pesantren An-Nur II Bululawang Malang sangat berpegang teguh, selama masih ada waktu gunakanlah sebaik mungkin.

Munurut Rudolf Pintner yang dikutip oleh purwanto (2011: 113) cara belajar yang efektif seperti menghafal, menegtik, mengerjakan soal. Waktu yang baik digunakan antara 20 sampai 30 menit, jangka waktu tersebut tidak berlaku untuk pelajaran yang membutuhkan pemanasan, teori ini yang menguatkan hasil penelitian di atas.

Faktor yang mendukung santri berprestasi di Pondok Pesantern AnNur II Bululawang Malang.

Dari hasil penelitian pembahasan sebelumnya, faktor apa saja yang mendukung santri berprestasi di Pondok Pesantren An-Nur II Bululawang Malang, faktor yang mendukung santri berpresatasi dimulai dari orang tua, peran orang tua sangatlah penting untuk seorang anak yang masih menempuh pendidikan sekolah, bagi santri orang tua yang tidak setiap hariberada di dekat mereka maka malalui komunikasi elektronik dan dukungan positif yang orang tua berikan dapat membangkitkan motivasi dalam diri santri, peran pembina kamar juga amat penting, selain sebagai pengawas santri di asrama, pembina kamar juga berperan sebagai wali santri pengganti orang tua selama di asrama, maka pembina kamar dituntut untuk memberikan semangat dan berwawasan luas, selain untuk membangkitkan motivasi belajar dalam diri santri digunakan juga apabila santri sewaktu-waktu bertanya, biasanya pembina kamar bekerja sama dengan wali kelas dan guru, faktor pendukung lainnya dari teman-teman dan lingkungan.

Faktor internal faktor dari dalam diri manusia, Faktor fisiologi yang bersifat fisik biasanya, karena sakit, arena kurang sehat, karena cacat tubuh. Faktor psikologi faktor yang bersifat rohani,Intelegensi, Golongan ini mempunyai potensi untuk dapat menyelesaikan pendidikan di Perguruan Tinggi. Seseorang yang memiliki IQ kurang dari 90 tergolong lemah mental, mereka inilah yang banyak mengalami kesulitan belajar. Bakat, Setiap individu mempunyai bakat yang berbeda-beda. Seseorang akan lebih mudah mempelajari sesuatu yang sesuai dengan bakatnya. Minat, Ada tidaknya minat terhadap suatu pelajaran dapat dilihat dari cara anak mengikuti pelajaran, lengkap tidaknya catatan dan aktif tidaknya dalam proses pembelajara. Motivasi, Motivasi dapat menentukan baik tidaknya dalam mencapai tujuan, sehimgga semakin besar motivasinya akan semakin besar kesuksesan belajarnya. Kesehatan mental, Hubungan kesehatan mental dengan belajar adalah timbal balik. Kesehatan mental dan ketenangan emosi akan menimbulkan hasil belajar yang baik demikian juga belajar yang selalu sukses 
akan membawa harga diri seseorang.

Faktor eksternal merupakan faktor yang berasal dari luar diri seseorang, seperti lingkungan keluarga karena keluarga merupakan pusat pendidikan yang utama dan pertama dan lingkungan sekolah.

Hasil penelitian tersebut didukung oleh teori dari Slameto (2003) faktor-faktor yang mempengaruhi prestasi belajar dapat digolongkan ke dalam dua golongan yaitu faktor internal yang bersumber pada diri siswa dan faktor eksternal yang bersumber dari luar diri siswa.

\section{SIMPULAN}

Berdasarkan penelitian yang telah dilakukan di Pondok Pesantren Wisata An Nur II Al Murtadlo , dapat diambil kesimpulan bahwa, cara belajar santri menentukan prestasi atau hasil belajar. Sebagian besar santri berprestasi memiliki cara belajar yang sempurna, yaitu memenuhi kriteria yang diberikan oleh peneliti, dengan kegiatan santri dari pagi sampai siang. Diwaktu siang disi dengan kegiatan pondok, dengan istirahat yang bias dikatakan sulit, namun santri tetap bias memilah waktu mana waktu bermain dan waktu untuk belajar. Sedangkan santri yang kurang berprestasi lebih dominan memiliki cara belajar yang kurang disiplin. Santri yang berprestasi tentunya akan lebih mudah dalam menerima materi pelajaran. Karena sebagian besar dari mereka telah berhasil memenuhi indikator cara belajar yang ditentukan peneliti. Santri yang mempunyai cara belajar yang baik, teratu dan disiplin akan menghasilkan prestasi belajar yang memuaskan dan begitu juga sebaliknya.

Berdasarkan hasil pembahasan, santri mengatasi waktu yang kurang efektif yaitu dengan memanfaat waktu kosong, seperti waktu akan sholat, dari asrama menyediakan waktu bersiap jamaah 1520 menit, bagi santri berprestasi waktu kosong harus dimanfaatkan dengan baik, tidak ada waktu yang tidak efektif, selama ada keinginan waktu dan tempat akan menjadi sahabat dan mendukung apa yang diinginkan. Santri berprestasi tidak menganggap kekurangan sebagai masalah, namun mereka senang karena diberikan kelebihan untuk mempelajari banyak hal, dari ilmu keagamaan yang tidak didapatkan di sekolah umum dan santri kekurangan akan ilmu pengetahuan umum sebab di sekolah santri diajarkan.

Berdasarkan hasil pembahasan, faktor yang mendukung santri berprestasi dapat berdampak pada perbedaan cara belajar santri berprestasi dengan santri yang kurang berprestasi adalah terletak pada motivasi belajar mereka yang melandasi semangat belajar mereka masing-masing. Motivasi dan semangat belajar yang tinggi cenderung dimiliki oleh santri yang berprestasi berupa cara belajar yang baik, memiliki jadwal belajar yang teratur, dan disiplin. Berbeda dengan santri yang kurang berprestasi, meraka tidak memiliki cara belajar yang baik, motivasi belajar rendah, tidak memiliki jadwal belajar, serta tidak melaksanakan kedisiplinan dengan sempurna, faktor yang santri dapatkan sama hanya saja motivasi dalam diri yang harus dibangkitkan, itu yang membedakan santri berprestasi dan kurang berprestasi.

\section{DAFTAR PUSTAKA}

Arylien L. B. 2014. Pengaruh Gaya Belajar Visual, Auditorial dan Kinestetik Terhadap Prestasi Belajar Siswa. Jurnal Kependidikan. 44 (22) : 168-174

Dhofier, Zamakhsyari. 1994. Tradisi Pesantren Studi Tentang Pandangan Hidup Kyai. Jakarta: LP3S.

Ernita T. 2016. "Hubungan cara Belajar dengan Prestasi Belajar Siswa dalam Mata Pelajaran PKn pada Siswa Kelas X SMA N 1 banjarmasin". Jurnal Pendidikan Kewarganegaraan. 6 (1): 69-77 
Malikatun. 2000. Studi Analisis Tentang Proses Pembaharuan Pendidikan di Pondok Pesantren Darul Falah Jekulo Kudus. Skripsi Kudus: Jurusan Tarbiyah STAIN.

Margono. 2007. Metodologi Penelian Pendidikan. Jakarta: Rineka Cipta.

Miftahudin. 2011. Tipologi Pondok Pesantren Dalam Konstelasi Pembaharuan Pendidikan Islam (Studi Pada Pesantren-Pesantren Di Kabupaten Kudus). Skripsi, Semarang: Fakultas Tarbiyah IAIN Walisongo.
Riyani, Y. 2012."Faktor-faktor yang Mempengaruhi Prestasi Belajar". Jurnal eksos. 8 (1):19-25

Sulaiman, D. 2013 menejemen ppendidikan pesantren modern dalam pembentukan karakter anak. Jurnal Al-Fikrah, 1(2).

Syarifuddin, A. 2011. Penerapan Model Pembelajaran Cooperative Belajar dan Faktor-FaktoryangMempengaruhinya". Jurnal Ta'bid.16(1) : 147-153 